\title{
Dinâmicas centrípetas e centrífugas na formação do Estado monárquico no Brasil: o papel do Conselho Geral da Província de São Paulo
}

Centripetal and centrifugal forces in the creation of the monarchic state in Brazil: the role of the General Council of the Province of São Paulo

Marisa Saenz Leme*

\section{Resumo}

O presente artigo avalia a formação e o funcionamento do Conselho Geral da Província de São Paulo durante o Primeiro Império. Organismo previsto na Constituição de 1824, com funções que podem ser consideradas um embrião do Poder Legislativo provincial, organizouse efetivamente na província de São Paulo em 1828, quando o governo de D. Pedro I já se desgastava. O significado de sua existência no contexto das dinâmicas centrífugas e centrípetas atuantes na primeira construção do Estado no Brasil independente constituem o principal objetivo da presente análise.

Palavras-chave: Legislativo; ordem; autonomia.

\section{ABSTRACT}

The present article examines the creation and development of São Paulo Provincial General Council during the First Empire of Brazil. As outlined in the Brazilian Constitution of 1824, the organ had functions that can be viewed as an embryonic provincial legislative power, and was actually established in the Province of São Paulo by 1828, when the government of Dom Pedro I was already becoming exhausted. The main focus of the present analysis is the significance of the Council's existence in the midst of the centrifugal and centripetal dynamics acting during the creation of Brazil's first independent state.

Keywords: legislative; order; autonomy.

\footnotetext{
${ }^{\star}$ Universidade Estadual Paulista (Unesp)/Franca, Rua Major Claudiano, 1880, Centro. 14400-690 Franca - SP - Brasil. saenzl@terra.com.br.
} 


\section{ENTRE O EXECUTIVO E O LEGISLATIVO,} A DISTRIBUIÇÃO DOS PODERES PROVINCIAIS

Como se sabe, São Paulo exerceu influência peculiar no processo de construção da monarquia constitucional no Brasil. No momento da Independência, embora a província não tivesse particular projeção socioeconômica, as elites paulistas, juntamente com as de Minas Gerais e do Rio de Janeiro, foram responsáveis pela articulação do modo como se processou a separação. Contudo, sua atuação não foi, como se pensava, homogênea: estudos recentes mostram a existência de graves e violentas dissidências no seu interior nessa época. ${ }^{1}$ Esse fator torna ainda mais instigante compreender como se alcançou a referida participação na condução do processo de independência e nos remete à análise da construção dos poderes provinciais em São Paulo, durante as primeiras etapas da montagem do Estado no Brasil independente. Perceber a província nesse escopo significa procurar visualizar simultaneamente a sua relação com o centro político em consolidação no Rio de Janeiro e as acomodações internas de sua elite.

Para tanto torna-se muito relevante saber como se estabeleceram, organizaram e funcionaram os conselhos de província. Apesar da centralização política característica do Primeiro Império, é fundamental salientar que existiu uma legislação geral que abriu espaços para a busca de relativa autonomia por parte das províncias. Essas possibilidades estavam presentes na criação dos mencionados conselhos, emanados de duas ordenações de origens diversas: a que instituiu os conselhos da presidência, ainda de autoria da Assembléia Constituinte e Legislativa das Províncias do Brasil, e a Constituição outorgada em 1824, na qual estavam previstos os conselhos gerais de província. Esses organismos permaneceram em funcionamento até a criação das assembléias provinciais, decorrente da parcial descentralização promovida em 1834 pelo Ato Adicional. ${ }^{2}$

O fato de a Carta de 1824 ter sido outorgada - elaborada com base num processo autoritário do governo central — não significou necessariamente a adoção no texto da lei de uma centralização absoluta dos poderes executivos. ${ }^{3}$ Pelo contrário, houve clareza na definição dos poderes legislativos, e não somente em nível central. Em relação às províncias, a previsão dos conselhos gerais implicava um embrião de Poder Legislativo, a ser devidamente acionado pelas respectivas elites políticas.

A dificuldade inicial para organização desses conselhos residiu na própria implementação da lei. Embora as instruções para as eleições dos conse- 
lho gerais — ordenando que se realizassem "pela mesma forma" da eleição de deputados para a Assembléia Geral Legislativa — fossem publicadas um dia após a promulgação da carta magna, ${ }^{4}$ houve grande atraso na sua execução, retardando-se a elaboração da legislação ordinária a respeito. Em São Paulo, província cujos representantes propugnavam pela efetivação da medida, o Conselho Geral instalou-se somente em $1^{\circ}$ de outubro de 1828. Entrementes, os paulistas implementaram de modo vigoroso o Conselho da Presidência Provincial, ${ }^{5}$ regido pela Lei de Organização dos Poderes Provinciais, elaborada na própria Assembléia Constituinte e Legislativa do Brasil (Carta de Lei de 20 out. $1823 \ldots$.., em Bonavides \& Amaral, v.1, 52.5, s.d.).

O Conselho da Presidência de São Paulo compunha-se do presidente da província, indicado pelo governo central, e de seis conselheiros, eleitos da mesma forma que para as juntas de governo provincial instituídas com a Revolução Constitucional do Porto de 24 de agosto de $1820 .^{6}$ Tinha por finalidades principais "fomentar o desenvolvimento agrícola, comercial, industrial, educacional e sanitário, estabelecer novas Câmaras e abrir estradas, catequizar índios e facilitar a lenta emancipação dos escravos" (art. 24 da Carta de Lei de 20 out. 1823).

Internamente à província, os poderes do Conselho em relação ao Executivo foram detalhadamente discriminados, sendo bastante amplos. Em face de uma série de questões, as mais importantes tocantes ao exercício da autoridade, o presidente só poderia direcionar sua atuação com a anuência desse organismo. Nesse escopo incluíam-se as difíceis relações com as autoridades judiciárias, permeadas de sérios conflitos, pois naquele momento se esboroavam as posturas coloniais e ainda não havia ocorrido a reestruturação do Judiciário. Da mesma ordem eram as relações com as autoridades militares.

A questão a ser ponderada quanto ao equilíbrio dos poderes reside nos espaços de autonomia da província em relação ao centro político do país em formação. Definindo detalhadamente o conjunto de atribuições do Conselho, a lei de outubro de 1823 rezava que suas "determinações ... seriam obrigatórias, enquanto não fossem revogadas, e se não opusessem às leis existentes" (Item 16, art. 24).

No que se refere às autoridades judiciárias e militares, as atribuições dos conselhos da presidência não implicavam princípios de distribuição de poder entre as províncias e o governo central, mas constituíam expedientes práticos para a solução de conflitos relativos a instâncias em princípio nacionais, porém naquele momento impossibilitadas de atuar, dada a reordenação institucional em curso. 
Quanto às finanças, regulamentou-se que esses conselhos teriam "à sua disposição para as despesas ordinárias, que demandar o desempenho das suas funções, a oitava parte das sobras das rendas da respectiva província" (art. 25 da Carta de Lei de 20 out. 1823). A eles também competia "determinar por fim as despesas extraordinárias, não sendo, porém, estas determinações postas em execução sem prévia aprovação do Imperador" (item 16, art. 24). Estipulava-se por fim que "a administração e arrecadação da fazenda Pública das províncias continuará a fazer-se pelas respectivas juntas, às quais presidirá, segundo a lei e regimentos existentes, o mesmo Presidente da província, e na sua falta aquele que o substituir" (art. 35).

No que diz respeito às atribuições que a legislação oriunda da assembléia constituinte dá ao Conselho da Presidência e a carta magna ao Conselho Geral, importa dimensionar as diferenças entre o que elas determinavam sobre as relações entre a província e o governo central. Considerando-se as disposições financeiras, entre o primeiro e o segundo Conselho teria havido, de acordo com Miriam Dolhnikoff, 7 uma regressão no sentido do abafamento das possibilidades de autonomia. A Carta de 1824 não estipulou poderes financeiros ao Conselho $\mathrm{Geral}^{8}$ e, no que tange ao Executivo das províncias, rezou brevemente sobre a sua articulação com o 'tesouro nacional':

A receita e despesa da fazenda nacional será encarregada a um tribunal, debaixo do nome de 'tesouro nacional', aonde em diversas estações devidamente estabelecidas por lei se regulará a sua administração, arrecadação e contabilidade, em recíproca correspondência com as tesourarias e autoridades das províncias do império. (art. 170)

Desapareceram ainda as tarefas de arbítrio em relação às autoridades judiciárias e militares, antes atribuídas ao Conselho da Presidência. Tal redefinição provavelmente decorreu da canalização dessas questões para a esfera central, em virtude da organização do Poder Judiciário.

Apesar dos mencionados limites do Conselho Geral de província, sobressaía na Carta de 1824 a sua valorização institucional, na forma de uma instância que se apresentou como embrião do Legislativo provincial. Significativamente, foi incluído no Título IV, “Do poder legislativo”, todo um capítulo dedicado ao Conselho: o V, "Dos Conselhos Gerais de Província e suas atribuições", em 18 artigos. ${ }^{9}$

Previu-se detalhadamente então a forma de funcionamento do Conselho, e seu escopo de representação foi largamente ampliado: para as "provín- 
cias mais populosas", ${ }^{10}$ o novo Conselho mais que triplicou legalmente o número de membros em relação ao Conselho da Presidência, de seis para 21 . Eliminou-se a obrigatoriedade da presença do presidente da província nas suas reuniões; pelo contrário, ele deveria se dirigir ao Conselho Geral apenas no momento da abertura do período anual das sessões, como depois se tornou procedimento habitual nas assembléias legislativas provinciais. ${ }^{11}$

À diferença do detalhamento existente para os conselhos da presidência, as atribuições do Conselho Geral de Província foram referidas de modo amplo, invocando-se concepções de cidadania. Rezava o primeiro artigo do capítulo: "A Constituição reconhece e garante o direito de intervir todo o cidadão nos negócios da sua província e que são imediatamente relativos a seus interesses peculiares” (art. 71 da Constituição de 1824). Tal direito deveria ser exercitado "pelas câmaras e pelos conselhos" (art. 72).

Quanto às efetivas possibilidades de os conselhos legislarem, seu uso é de delicada avaliação. De um lado, eles eram instados à elaboração de projetos, na medida em que lhes cabia "propor, discutir e deliberar sobre os negócios mais interessantes das suas províncias ... formando projetos peculiares e acomodados às suas localidades e urgências" (art. 81). Contudo, não se poderia "propor, nem deliberar nestes conselhos projetos sobre interesses gerais da nação", que, observe-se, permaneciam indefinidos; tampouco se poderia deliberar sobre "quaisquer ajustes de umas com as outras províncias" ou sobre "imposições, cuja iniciativa é da competência particular da Câmara dos Deputados".

Eram três as matérias de "iniciativa privativa” desta última casa: os "impostos", os "recrutamentos" e "a escolha da nova dinastia, no caso da extinção da imperante" (art. 36). Naturalmente, as duas primeiras questões eram definidoras da construção do poder central do Estado na superação de uma situação confederativa, incidindo diretamente sobre as províncias. Mas também se firmava nacionalmente - malgrado a força atribuída ao Poder Executivo na Carta de 1824 - a primazia do Legislativo nesse sentido. O que remete às possibilidades liberais do Estado em formação.

No que se refere às províncias, com destaque para o papel desempenhado pela Câmara dos Deputados, articulou-se legalmente um modo de proceder em que as 'deliberações' dos seus conselhos gerais teriam larga acolhida no governo central, ainda que não fossem autônomas.

As "resoluções" do Conselho seriam remetidas, "por intermédio do Presidente da Província” ao "poder executivo" (art. 84), e, estando "a assembléia geral ... reunida", ser-lhe-iam "imediatamente enviadas, pela respectiva secre- 
taria de Estado, para serem propostas como projetos de lei, e obter a aprovação da assembléia por uma única discussão em cada câmara" (art. 85). No caso de recesso da assembléia, o imperador as mandaria "provisoriamente executar" se as julgasse "dignas de pronta providência, pela utilidade que de sua observância” resultaria “ao bem geral da província” (art. 86). Não havendo, porém, avaliação imediatamente positiva, o Imperador suspenderia "o seu juízo a respeito daquele negócio” e aguardaria a reunião da Assembléia, para que esta pudesse deliberar conforme estipulado.

A Constituição de 1824 insistiu ainda na forma de organização do Conselho Geral, ao prever que "o método de prosseguirem em seus trabalhos e sua polícia interna e externa, tudo se regulará por um regimento, que lhe será dado pela assembléia geral” (art. 89). Esse regulamento foi efetivamente elaborado e posto em prática, o que chama a atenção num cenário em que de um modo geral a feitura da legislação complementar necessária ao cumprimento dos dispositivos constitucionais tanto tardava. Um de seus artigos, o 39, versava expressamente sobre a apresentação de projetos.

No contexto do Primeiro Império, a efetivação dos conselhos gerais de província foi medida propugnada pelos liberais e largamente desejada pelas elites políticas paulistas.

\section{O Conselho Geral de Província em São Paulo}

O Conselho Geral da Província de São Paulo constituiu-se e teve seu primeiro desenvolvimento exatamente quando se aguçou a crise do Primeiro Império, no período em que, extinta a guerra externa - com a derrota do Brasil na questão da Cisplatina e a formação da República do Uruguai —, as tensões internas puderam vir à tona com plena força.

Instalado em $1^{\circ}$ de outubro de 1828 , ele completou uma legislatura ${ }^{12}$ sob D. Pedro I, encontrando-se no início da segunda quando da Abdicação. Nesses pouco mais de dois anos foi intensa a sua atividade, que se desdobrou em vários planos. Se de um lado o fundamento das temáticas socioeconômicas nele tratadas permaneceu bastante semelhante ao das questões antes discutidas no Conselho da Presidência, de outro se observa uma ofensiva muito consistente e organizada para a implementação de projetos que dessem forma às soluções aventadas. Tratou-se de uma outra dinâmica de poder que levou ao surgimento de novos projetos para a solução de questões mais antigas. ${ }^{13}$

De acordo com o estipulado no artigo 39 do Regimento dos Conselhos 
Gerais, logo na abertura dos trabalhos da primeira legislatura, um dos seus eminentes conselheiros, nada menos que o futuro regente do Império, o padre Diogo Antonio Feijó, organizou dois livros em separado. ${ }^{14}$ Um para o registro de projetos e propostas a serem feitas pelos conselheiros individualmente ou pelas comissões constituídas no Conselho, e outro para as representações. Esse material foi remetido às instâncias executiva e legislativa do governo central para a devida apreciação e aprovação.

Diversas das temáticas que se apresentaram nesses livros versavam sobre a sistematização da vida da província. Dentre elas estavam as estradas, que já em demandas anteriores constituíram um foco privilegiado das atenções, quer se tratasse da abertura de novos caminhos ou desvios, quer da sua conservação. Havia mesmo um ousado projeto para a criação de um Banco Provincial com o objetivo exclusivo de angariar recursos para elas.

A devida viabilização dos caminhos interessava diretamente ao comércio e à lavoura cuja produção o alimentava. Mas não foi somente da circulação comercial que trataram os conselheiros. A questão da posse da terra foi alvo de detalhado projeto, também do padre Feijó. Tratava-se de um aspecto crítico da organização socioeconômica do Brasil da época, pois havia um 'vazio legal' a respeito da propriedade da terra, uma vez que se extinguira a ordenação colonial, centrada na doação de sesmarias, e nada ainda se colocara em seu lugar. No projeto em apreço procurou-se detalhar sistematicamente as possibilidades de acesso à terra, seja por concessão de sesmarias, seja por compra ou troca. Por esse projeto limitava-se apuradamente o tamanho das propriedades e a determinava-se a preservação de áreas de mata virgem, o que indica preocupação com a produtividade e a preservação do solo. De forma liberal, o acesso à terra era possibilitado aos “emancipados" e "estrangeiros".

Os conselheiros cuidavam também das possibilidades fabris e da diversificação do cultivo na província, estimulando novas plantações. Foi este o caso das tentativas de introdução de vinhas nos arredores de São Paulo. Tais intentos levavam à problemática questão da transformação da mão-de-obra: uma comissão do Conselho foi encarregada de analisar o relatório do governo sobre a colônia alemã que se estabelecera em Santo Amaro.

Desenvolver o comércio e a agricultura e, na medida do possível, a indústria, implicou a busca de racionalidade científica. Surgiu então, por intermédio do conselheiro Gurgel, proposta de organização administrativa "relativa à Estatística da Província"; ademais, em moldes que lembram a criação das academias no século XVIII, no auge da Ilustração luso-brasileira, propôs- 
se a fundação de uma "Sociedade Econômica", cujos objetivos e estatutos despertam bastante curiosidade e reflexão.

Propunha-se tal sociedade a "recolher as notícias históricas, e as produções do vasto território da nossa Província, que possam ser úteis, e interessantes à Agricultura, às Pescarias, às Artes, Ofícios, e Fábricas; e ao Comércio, tanto interno, como externo da mesma". Intentava reunir "Homens Sábios e Cidadãos zelosos, que apliquem a tão importantes fins os resultados práticos da Física, Mecânica, Química, Mineralogia, História Natural, e Economia”. Esses estudos teriam incentivos financeiros: à sociedade caberia fornecer auxílio pecuniário para "Lavradores e Artistas ... dirigirem seus ensaios e experiências", disponibilizando-se ainda "livros, modelos, máquinas e instrumentos” para tanto. Previa-se também a distribuição de prêmios aos melhores trabalhos.

Importa salientar as concepções sobre as relações entre as esferas pública e privada expostas no preâmbulo do projeto de criação da mencionada sociedade. Considerando-se "a Agricultura em toda a sua extensão e a Industria fabril" como bases da "riqueza nacional", afirmava-se que para promovê-las cumpria "fazer conspirar as forças do Governo, e dos particulares, a um centro comum". A “Sociedade" intitulava-se uma "Associação patriótica”, e um dos objetivos dos prêmios a serem instituídos era o de "estimular o patriotismo dos Cidadãos". Nesse sentido, ressaltava-se o alcance cívico-didático do projeto: o resultado dos trabalhos dever-se-ia "publicar, por meio da Imprensa, em Memórias e Instruções...", com vistas a se "espalhar a instrução pública nos ramos da sua competência, comunicando a nossos compatriotas" os resultados dos estudos desenvolvidos.

A carência de imprensa na Província levou o conselheiro Costa Carvalho, futuro marquês de Monte Alegre, a escrever um documento "pedindo-se ao Governo de S.M.I. uma Tipografia” que, inicialmente, seria "para se publicarem os atos da Administração Provincial”. Entre outros, um argumento utilizado na justificativa dessa solicitação denota preocupação com a informação pública: afirmava-se ser "a publicidade em todos os seus atos da essência do Governo Representativo”.

Quanto à educação, foram várias as propostas e representações sobre a sua expansão, sobressaindo a afirmação de concepções laicas em detrimento do ensino religioso. Os conselheiros também se dirigiam ao governo central solicitando auxílio para a construção de uma biblioteca pública na cidade de São Paulo. No pólo oposto, normatizavam ainda as relações societárias com índios e escravos, procurando estabelecer-lhes princípios 'civilizados'. 
Porém, o ordenamento das relações administrativas no interior da província, envolvendo as relações com e entre as autoridades militares e judiciárias - que tivera um grande impulso sob o Conselho da Presidência — atenuou-se sob o Conselho Geral, em virtude da nova ordenação dessas relações na esfera central, promovida com a criação do Supremo Tribunal de Justiça, em setembro de 1828. Prosseguiu, contudo, a padronização dos procedimentos relacionados às câmaras municipais, que já demandara intensa atividade do primeiro Conselho.

Pela lei de $1^{\circ}$ de outubro de 1828 - registre-se a coincidência da data com o início do funcionamento do Conselho Geral de Província de São Paulo - as câmaras municipais do Império ficaram claramente subordinadas à esfera provincial de poder. A implementação de propostas importantes feitas pelo conselho paulista, como o levantamento estatístico ou a regularização das datas de terra, exigia a atuação organizativa e fiscalizadora das câmaras nas respectivas localidades; ao mesmo tempo, seus procedimentos eram duramente regulamentados pelo Conselho Geral, pois elas tendiam a agir cada uma a seu modo e relutavam em aceitar a ação normativa do Poder Provincial. Cabia também ao Conselho decidir sobre a criação de vilas e freguesias.

Simultaneamente à elaboração de projetos e propostas visando à ordenação geral da vida socioeconômica, cultural e administrativa da província, evidenciaram-se nas atividades do Conselho Geral de São Paulo posicionamentos diretamente afetos aos impasses do relacionamento entre as esferas de governo provincial e central, implicando entendimentos de processos centralizadores e federalistas no que diz respeito à distribuição dos poderes políticos e à direção financeira do Estado nacional em construção.

\section{LUTA POLÍTICA E CONCEPÇÕES DE ESTADO}

Diferentemente do que até então se verificara nas relações dos paulistas com o governo central, quando os posicionamentos políticos eram indiretos, o Conselho Geral de São Paulo realizou manifestações explicitamente políticas, apresentando seu pensamento sobre as relações entre a província e o centro, a articulação dos poderes Legislativo e Executivo, e os fatos mais imediatos da política na corte. Os conselheiros mostraram-se afinados com a Câmara dos Deputados em sua luta para impor-se ao Executivo e manifestaram-se claramente sobre as disputas ministeriais entre o que veio a se constituir co- 
mo o 'partido brasileiro' e o 'português', próximo a D. Pedro I e acoimado de absolutista.

Saliente-se que os rituais de instalação e os mecanismos formais de relação entre os poderes em constituição naquele período são indicativos das tensões então existentes. A primeira medida do Conselho foi comunicar o ato de sua instalação às diferentes instâncias de poder central, com ofícios de diferentes teores ao imperador e à Câmara dos Deputados; quanto ao Senado, coube-lhe uma cópia do último, o que é significativo da indisposição dos paulistas em relação a essa casa. Registre-se também o que aparentemente é mero detalhe: embora os ofícios tenham sido encaminhados ao ministro do Império para que, de acordo com a praxe estipulada, ele os despachasse aos destinatários, o ofício da Câmara foi também diretamente remetido ao seu secretário.

No texto enviado pelo Conselho Geral de São Paulo ao imperador reafirmaram-se princípios políticos básicos da Constituição de 1824. Enalteciase o "Código Sagrado" obtido pela nação por intermédio de D. Pedro I, asseverando-se que a carta magna evidenciava o reconhecimento do imperador de que, "em sua Sublime Razão, os homens, entrando em Sociedades políticas, não perdem jamais seus Direitos naturais". Enfatizava-se terem sido esses direitos consagrados no art. 71 da Constituição, que instituíra "o principio de Direito Público Universal ... de que todo o Cidadão tem o direito de intervir nos negócios de suas Províncias, como aqueles que mais interessam à felicidade particular, da que essencialmente depende a felicidade publica”. Em decorrência desses princípios, louvava-se nesse texto a promulgação da até então faltante lei regulamentar, "que fizesse por em andamento a preciosa instituição dos Conselhos Gerais de Província”.

Por sua vez, o manifesto enviado à Câmara pelo Conselho paulista deixava claros pontos fundamentais da alegada "felicidade particular", pensada em harmonia com o todo em que se achava inscrita. Delineou-se claramente uma concepção de Estado em que a desejada autonomia liberal e a constituição de um núcleo centralizado de poder surgiam como complementares, diluindo-se o antagonismo de que se ressentiam as propostas de cunho na realidade confederativo, na aparência mais radicalmente liberais.

Dessa maneira o Conselho, "em nome dos povos que representava", rendia à Câmara "as devidas graças pela Lei, que fez por em execução os Conselhos Gerais das Províncias”. Antecipando que os paulistas apreciariam "em seu justo valor esta tão grande instituição", afirmava-se que o devido reconhecimento do escopo provincial consagraria a Independência e se constitui- 
ria no objetivo nacional: "firmando assim o bem ... de cada uma das Províncias, fareis a felicidade da Nação inteira ... o remate do edifício social erguido com a Independência do Império".

Nesse quadro desenvolveu-se a ação do Conselho, que, com responsabilidade, se dispunha a colaborar para "ministrar-Vos Projetos de Leis adequadas às circunstancias desta província”. Os paulistas ainda alegravam-se por ver na efetivação do Conselho Geral "a maior garantia de seus direitos", e clamavam contra o que consideravam injustiças historicamente cometidas contra São Paulo, não havendo clara razão para que uma província, "tão brindada pela Natureza ... não tenha chegado àquele grau de importância, de que é capaz".

Contudo, ao mesmo tempo em que se valorizava a perspectiva regional, salientava-se a importância da ação central. Na visão dos conselheiros, a obra provincial só se completaria se devidamente apoiada pelo poder central: tendo o Conselho informado à Assembléia Geral os "males que pesam ... sobre os povos desta Província”, poderiam os deputados, "como Guardas da Constituição", dar os "prontos remédios, que convierem”. Os conselheiros enalteciam as possibilidades de uma ação combinada entre a Assembléia Geral Legislativa e o Conselho Geral da Província de São Paulo.

Procurou-se ainda nesse texto afirmar a imagem dos paulistas como patriotas e legalistas, características que justificariam a interação harmônica entre a província e o poder central, representado no Legislativo. Os paulistas declaravam-se "possuídos do nobre entusiasmo pelas prosperidades da Pátria, entusiasmo que formou sempre o Caráter paulistano". Em conseqüência, "tão obedientes à Lei, quanto ciosos de seus Sagrados Direitos” levariam ao conhecimento da Câmara "qualquer infração de lei, qualquer falta de Justiça".

A lógica da defesa da monarquia constitucional evidenciou-se em outras duas manifestações realizadas pelo Conselho antes da abdicação de D. Pedro I, envolvendo impasses políticos então agudamente vividos na corte. De um lado, tratou-se da disputa entre 'brasileiros' e 'portugueses' para cargos no Ministério; de outro, das relações entre a Câmara dos Deputados e o Senado. ${ }^{15}$

A crise aberta no governo de D. Pedro I pela reforma do Ministério teve em fins de 1829 uma solução favorável aos 'brasileiros', que, além dos cargos pretendidos, foram contemplados não só com o afastamento para Portugal do conselheiro particular do imperador e influente membro da política governamental, Francisco Gomes da Silva - vulgarmente conhecido como "O Chalaça” - como também com o desmantelamento em Pernambuco da sociedade absolutista "Os Colunas". De acordo com John Armitage, "enfim prin- 
cipiaram a aparecer esperanças de que o Governo, adotando uma linha de conduta mais nacional, adquirisse a confiança e a estima que até então nunca pudera grangear" (Armitage, 1981, p.199).

A elite política paulista manifestou-se abertamente sobre a questão, adotando a postura emblemática dos que procuravam fazer pender o fiel da balança do Executivo, representado pela figura do imperador, para os seus posicionamentos particulares. Intitulando-se "o órgão fiel dos seus habitantes", o Conselho Geral da Província enviou ofício a S.M.I. (Sua Majestade Imperial) "agradecendo em nome da Província inteira o ter desfeito a trama dos absolutistas". Afirmando-se serem os "sentimentos dos Paulistas ... concordes com o Brasileiro, o Constitucional Coração de V.M.”, evidenciou-se no texto o possível teor bélico da defesa da monarquia constitucional. ${ }^{16}$ Considerando-se "mais ilustrados, porém não menos bravos que seus antepassados", para quem "a liberdade, a independência, e o seu Monarca eram objetos santos ... os Paulistas d'hoje não esperariam em seu solo os rebeldes, antes ... a Província se transportaria em massa ... para arrancar a Sagrada Pessoa de S.M.I. a qualquer coação, que traidores lhe quisessem impor".

Embora saudando as formas legais, "os meios tão simples, quanto eficazes, com que V.M. desfez a trama liberticida”, enfatizou-se dramaticamente no final do documento que os paulistas sustentariam "a Monarquia Constitucional a despeito dos maiores sacrifícios", e que o despotismo não levantaria "jamais seu Trono, senão sobre as ossadas do derradeiro Paulista".

A par da reorganização ministerial, os poderes parlamentares do Senado e da Câmara foram matéria de contínua disputa no Primeiro Império. Tratava-se de um acirrado embate da maioria da Câmara contra o Senado e o imperador no que tange à estruturação jurídica dos poderes de Estado. Para os deputados, o atraso na elaboração legislativa decorria da falta de presteza do Executivo, ou do Senado, no exame dos projetos oriundos da Câmara. A elaboração de projetos foi bastante profícua, como bem mostrou Pedro Octávio Carneiro da Cunha (1985), residindo grandemente a morosidade da conclusão dos trabalhos nas instâncias politicamente combatidas pela Câmara dos Deputados. ${ }^{17}$ Esta acusava continuamente o Executivo de violar a Constituição; por sua vez, as críticas não se cingiam à figura real, configurando uma acirrada disputa com os ministros e conselheiros de Estado.

Nesse cenário, foi fundamental a luta em âmbito nacional pela fusão das duas instâncias do Poder Legislativo, medida intensamente propugnada pelos mais liberais. Somente dessa forma seria possível a aprovação das leis elaboradas na Câmara, que ficavam 'presas' no Senado, implicando a medida na 
existência de um Legislativo radicalmente liberal. ${ }^{18}$ A proposta foi vencedora ao final do Primeiro Império, tendo sido grandemente aplaudida no Conselho Geral de São Paulo, que enviou representações ao imperador, à Câmara de Deputados e ao Senado em congratulação pelo ato, que, de acordo com a fala dos conselheiros, significava "a verdadeira e literal observância do art. 61 da Constituição”. Rezava o aludido artigo:

Se a Câmara dos Deputados não aprovar as emendas ou adições do Senado, ou vice-versa, e todavia a câmara recusante julgar que o projeto é vantajoso, poderá requerer, por uma deputação de três membros, a reunião das duas câmaras, que se fará na Câmara dos Senadores, e conforme o resultado da discussão se seguirá o que for deliberado.

O teor das manifestações do Conselho Geral de São Paulo variou de acordo com o destinatário. Enalteceram-se o labor da Câmara dos Deputados e o empenho do imperador; mas isso secamente, o que foi natural em face da resistência daquela casa à reunião conjunta. Agradeceu-se a aquiescência do Senado. Saliente-se, contudo, o fato de ter havido um endereçamento a essa instância, à qual o Conselho não tinha o hábito de dirigir-se diretamente.

Em relação à Câmara, chamada no texto de "Augusto Templo da Liberdade Brasileira", manifestava o Conselho, juntamente com o "Povo Paulistano ... os tributos de gratidão e amor que consagram aos seus Legisladores ... incansáveis em servir á Pátria" e que naquele momento acabavam "de facilitar a consecução de Leis importantes, que o Brasil esperava", havendo com isso dado "um impulso forte à liberdade, e prosperidade da Nação", resultado da "coragem, firmeza e sabedoria" dos deputados.

Quanto ao texto enviado ao imperador, ressalte-se a valorização da identidade regional feita no documento, sendo os paulistas referidos como um 'povo' particular no contexto da nação. Apresentando-se o Conselho como “órgão de um Povo, que sabe prezar sua Constituição Política, e respeitar o Monarca que jurou sua observância e guarda ... um povo, que já tem saboreado as doçuras da liberdade, que pela própria experiência tem já comprovado a vitalidade e os gozos de uma Nação regida pelo sistema Constitucional", considerou-se que "a constituição era até hoje quase letra morta", dada a inexistência das "Leis regulamentares que podiam vivificá-la" e desembaraçá-la dos "velhos atavios do Despotismo". Naquele instante, porém, "com a esperança dessas leis indispensáveis, o Povo Paulistano" tinha "a dita de ver firmada a paz, e a segurança do Estado, e removidas para longe essas negras som- 
bras, que começavam a toldar o horizonte político, e prognosticavam um horrendo futuro". Nesse quadro, elogiou-se S.M.I. "pelo emprego de uma das mais preciosas atribuições do Poder Moderador, qual a de convocar extraordinariamente a Assembléia Geral".

\section{ProjeTOS ECONÔMICOS E AUTONOMIA... NA ORDEM!}

A questão política de fundo, referente à combinação de formas centralizadas - executivas e legislativas - do poder de Estado com as possibilidades de autonomia provincial, apresentava-se necessariamente nos projetos de cunho econômico, explicitamente no que diz respeito aos recursos financeiros.

Quando da reordenação político-administrativa decorrente da Revolução do Porto, com a formação da primeira Junta de Governo da Província, os paulistas aderiram ao governo estabelecido no Rio de Janeiro, e não a Lisboa, o que, como se sabe, constituiu uma atitude fundamental em direção à forma assumida pelo Estado no Brasil. Contudo, simultaneamente, os conselheiros manifestaram-se ciosos da sua autonomia financeira: protestaram "obediência a D. Pedro" em todos os aspectos necessários, "menos no que toca a mandar dinheiro". ${ }^{19}$ Postura radical, pois evidencia um entendimento confederativo do Estado em constituição.

Para afirmar seu poder, o Governo Provisório (eleito logo após a Independência) solicitou por sua vez que se designasse como presidente da Junta da Fazenda Provincial, organismo responsável pela organização financeira da província, "aquele Membro, ou Deputado do Governo" que ele próprio nomeasse; manteve-se no posto o já então presidente, por ser "um dos Membros deste Corpo Moral".

O principal aspecto da autonomia financeira naturalmente dizia respeito à distribuição dos recursos tributários. Cabe lembrar que o monopólio fiscal, como poder do governo central de se impor economicamente às suas partes componentes, foi elemento fundamental para a constituição do Estado moderno, centralizado. ${ }^{20}$ Com o fim do monopólio tributário exercido pela coroa portuguesa na colônia, o Estado liberal em formação, que buscava manter a unidade territorial do Brasil com base na direção do Rio Janeiro, precisava reconstruir esse monopólio, o que levou a intensos conflitos com as províncias. ${ }^{21}$

Na trajetória política do Conselho Geral da Província de São Paulo observa-se uma oscilação entre a valorização da autonomia provincial e o reco- 
nhecimento da necessidade de construir um poder financeiro central para implementar um governo de caráter nacional.

Logo no início dos trabalhos da primeira legislatura surgiram dois projetos para a criação de um "Banco Provincial” em São Paulo, "em beneficio das Estradas". "As hypothecas", ou seja, os recursos para tal empreendimento, além da contribuição de particulares, adviriam substancialmente das arrecadações feitas nos caminhos de Cubatão, de Santos, das Vilas do Norte, do caminho de Curitiba, bem como "das estradas, que o Comércio, e a lavoura" utilizavam "nos seus transportes do interior para fora da Província”. Num dos projetos, o do Conselheiro Veiga, estipulava-se também que "todos os impostos pagos por esta Província ao Banco do Rio de Janeiro" fossem decretados "para o fundo do Banco desta mesma Província, por isso que este estabelecimento é em benefício peculiar do seu mesmo Comércio”.

Num momento de reordenação financeira, em que a situação do Tesouro Nacional era crítica, com o fechamento do Banco do Brasil e a falta de circulação monetária, as propostas oriundas de São Paulo, mais do que significar um esvaziamento do poder central, poderiam apenas indicar uma tentativa de suprir as carências de organização geral nesse sentido. Ambos os projetos se referiam à filial do Banco do Rio que existia na província e estava a findar-se.

No mesmo sentido se pode avaliar a solicitação do Conselho a S.M.I., feita por meio de proposta do Sr. Álvares Machado, para que se autorizasse a cunhagem de cobre na capital da província, já permitida em períodos anteriores. A justificativa fala por si:

Nenhum de nós ignora o vexame que pesa sobre os habitantes desta Capital, e que já se vai estendendo sobre toda a Província com o desaparecimento das Notas do Banco. Deixando de parte as causas remotas, e antigas deste mal ... é incontestável que a Causa imediata ... é ser pequena a quantidade da moeda de cobre em giro, o que se verifica pelo pronto desaparecimento dela.

De acordo com o documento, não haveria carência de numerário se a reprodução da cunhagem na própria província fosse possível. A ambigüidade da questão financeira, cindida entre a relativa autonomia do poder provincial e o controle, fiscalização e padronização contemplados na construção de um Estado de cunho nacional, explicitava-se nas representações do Conselho. De um lado, registravam-se queixas contra o que foram consideradas "imposições" indevidas do Executivo nesse terreno. Mas de outro também se intitulava "anticonstitucional" o pagamento desigual de impostos (custas) no inte- 
rior da província, propugnando o Conselho pela sua padronização. Os impostos foram tratados como "Direitos Nacionais" num documento que envolvia a relação do governo provincial com a comarca de Curitiba.

Observa-se que realizar projetos destinados à viabilização de uma economia mais autônoma da província e simultaneamente inserir-se nas padronizações que se elaboravam nacionalmente constituíam procedimentos que, se de um lado se apresentavam como conflitantes, de outro revelavam aspectos complementares entre as esferas provincial e central do poder em construção. Para o governo provincial, era fundamental impor sua autoridade às diferentes regiões da província, em particular às câmaras municipais.

Sintomática dessa situação foi a proposta feita em dezembro de 1829 pelo conselheiro Tobias de Aguiar solicitando que se igualassem "as medidas em toda a província pelo padrão que serve na Capital do Império”, o que se constituía num "dos meios mais eficazes de se evitar as fraudes, como de facilitar as transações comerciais". O projeto de padronização, com alcance nacional, implicava também o fortalecimento do poder provincial sobre os particulares e as câmaras. Estas ficariam "obrigadas a ter o dito padrão para os aferimentos" (art. 3), penalizando-se como falsificadores “todos que usassem d'outras medidas" (art. 4).

Em fins de 1830, num dos tópicos abordados na manifestação de júbilo enviada à Câmara dos Deputados pelo início da efetivação das leis complementares à Constituição, o Conselho Geral da Província de São Paulo destacava a importância de ter havido o "reconhecimento do preceito Constitucional da anuidade dos impostos, princípio vital do sistema representativo" bem como a elaboração da Lei do Orçamento, "que a esta hora já terá recebido a Sanção de V.M.I. a esboçar o plano da remissão da enorme dívida Nacional, germem destruidor de toda a prosperidade".

Como se depreende das posturas que prevaleceram no Conselho Geral da Província às vésperas da Abdicação, não obstante a força centrífuga das demandas econômicas em relação ao governo central, importava aos paulistas, sobretudo, a configuração de uma ordem, e não uma desordem, financeira nacional, como melhor elemento para a própria existência provincial. Afirmar a soberania central em detrimento do controle financeiro provincial evidencia a superação entre as elites paulistas dos conceitos confederativos e a incorporação da concepção do Estado-nação, que, como já mencionado, se organizou com base num núcleo central que se impôs às partes independentemente da forma, centralizada, como no caso francês, ou federativa, como nos Estados Unidos. 


\section{NOTAS}

${ }^{1}$ Para tanto, veja-se: DELATORRE, V. A. São Paulo à época da Independência. Contribuição para o estudo do chamado movimento "bernardista”, 1821/1823. São Paulo, 2003. Dissertação (Mestrado em História) — Faculdade de Filosofia, Letras e Ciências Humanas, Universidade de São Paulo; e RICCI, M. Nas fronteiras da Independência: um estudo sobre os significados da liberdade na região de Itu. Campinas, 1993. Dissertação (Mestrado em História) — Instituto de Filosofia e Ciências Humanas, Universidade Estadual de Campinas.

${ }^{2}$ Para a realização do presente trabalho, cotejaram-se as fontes específicas para São Paulo com a legislação geral do Império pertinente à temática. Para São Paulo a base documental consistiu nas Atas do Conselho Geral da Província: 1828-1831. Arquivo Público do Estado de São Paulo, Caixa L06148. Livro 3: Registro de propostas, ofícios e representações, que subirem à Presença de S.M.I. e da Assembléia Geral Legislativa; e Livro 9: Registro das propostas originais apresentadas pelos Conselheiros, ou Comissões, conforme o artigo 39 do Regimento interno do Conselho. Este material foi fundamental para a apreensão da dinâmica que se desenrolou nas dimensões socioeconômicas, culturais e políticas do Conselho Geral da Província. Por seu intermédio desvendam-se tanto as relações intraprovinciais quanto os direcionamentos impressos no trato com o governo central. No que se refere à legislação do Império, utilizou-se a "Constituição Política do Império do Brasil". In: ALMEIDA, F. H. M. (Org.) Constituições do Brasil. 2.ed. São Paulo: Saraiva, 1958, p.949, com especial atenção para o Capítulo V do Título IV, e a "Carta de Lei de 20.10.1823, dando nova forma aos governos das províncias, criando para cada uma delas um presidente e Conselho". Leis da Assembléia Geral Constituinte e Legislativa das Províncias do Brasil. In: BONAVIDES, P.; AMARAL, R. Textos politicos da História do Brasil, v.1, 52.5. Disponível em: www.cebela.org. br/txtpolit. A análise dessa legislação é básica para se reconstituir a ossatura jurídico-institucional em que se movia a ação provincial.

${ }^{3}$ Para a rediscussão das caracterizações políticas do Primeiro Império, veja-se: OLIVEIRA, C. H. de Salles. O poder moderador e o perfil do Estado Imperial: teoria política e prática de governar (1820-1824). In: MALATIAN, T.; LEME, M. S.; MANOEL, I. A. (Org.) As múltiplas dimensões da política e da narrativa. São Paulo: Olho d’Água, 2004.

${ }^{4}$ Sobre o assunto, consultar: DEBES, C. Estrutura política e legal dos governos paulistas de 1821 a 1834. Revista do Instituto Histórico e Geográfico de São Paulo, São Paulo, v.65, 1968.

${ }^{5}$ Para o estudo do Conselho da Presidência Provincial de São Paulo, veja-se: LEME, M. S. São Paulo no Primeiro Império: poderes locais e governo central. In: OLIVEIRA, C. H. de Salles; PRADO, M. L. C.; JANOTTI, M. L. de Monaco (Org.) A história na política, a política na história. São Paulo: Alameda, 2006.

${ }^{6}$ Em relação a estas, a diferença foi que a Constituinte acabou com o presidente eletivo.

${ }^{7}$ Construindo o Brasil: unidade nacional e pacto federativo nos projetos das elites (1820- 
1842), São Paulo, 2001. Tese (Doutorado) — Faculdade de Filosofia, Letras e Ciências Humanas, Universidade de São Paulo, p.72-73. Veja-se também da mesma autora: O Pacto Imperial: origens do federalismo no Brasil. São Paulo: Globo, 2005.

${ }^{8}$ Somente a Câmara dos Deputados poderia tomar iniciativas nesse sentido. Por sua vez, o Conselho da Presidência, embora tivesse um recurso a ele destinado, também não poderia tomar iniciativa a respeito da questão.

${ }^{9}$ Constituição Política do Império do Brasil. In: ALMEIDA, 1958, p.9-49.

${ }^{10}$ Eram elas: Pará, Maranhão, Ceará, Pernambuco, Bahia, Minas Gerais, São Paulo e Rio Grande do Sul; nas outras o Conselho seria de treze membros (art. 73).

${ }^{11}$ Sobre as Assembléias Provinciais, consulte-se: SILVA, C. F. da. A casa habitada: a Assembléia Legislativa Paulista (1835-1842). Franca (SP), 2003. Dissertação (Mestrado em História) — Faculdade de História, Direito e Serviço Social, Universidade Estadual Paulista.

${ }^{12}$ Os mandatos eram então de dois anos.

${ }^{13}$ Sobre a história dos governos paulistas entre a revolução do Porto e o fim do Primeiro Império, consulte-se: DEBES, C. Estrutura política e legal dos governos paulistas de 1821 a 1834; e GOMES, Alfredo. Primeiros governos provinciais, ambos na Revista do Instituto Histórico e Geográfico de São Paulo, São Paulo, v.65, 1968; OBERACKER JR., C. H. O movimento autonomista no Brasil: a província de São Paulo de 1819 a 1823 . Lisboa: Cosmos, 1977.

${ }^{14}$ Atas do Conselho Geral da Província: 1828-1831. Caixa L06148. Arquivo Público do Estado de São Paulo. Livro 3: Registro de propostas, ofícios e representações, que subirem à Presença de S.M.I., e da Assembléia Geral Legislativa; Livro 9: Registro das propostas originais apresentadas pelos Conselheiros, ou Comissões, conforme o artigo 39 do Regimento interno do Conselho.

${ }^{15}$ Sobre essas questões, consulte-se sobretudo: ARMITAGE, J. História do Brasil, desde o período da chegada da Família de Bragança, em 1808, até a Abdicação de D. Pedro I em 1831. Belo Horizonte: Itatiaia; São Paulo: Edusp, 1981; CUNHA, P. O. da. A fundação de um império liberal. In: História Geral da Civilização Brasileira, 6 ed. São Paulo, Difel, t.II, v.1, 1985; MONTEIRO, Tobias. O Primeiro Reinado. São Paulo: Edusp; Belo Horizonte: Itatiaia, v.2, 1982.

${ }^{16}$ Sobre a arregimentação política e militar dos paulistas em defesa da monarquia constitucional no momento da Abdicação, veja-se: WERNET, A. Sociedade políticas. São Paulo: Cultrix; Brasília: INL, 1978.

${ }^{17}$ Comprova-o o "Índice Cronológico das Leis e Decretos formulados pela Assembléia Geral Legislativa do Império do Brasil, na sua primeira legislatura de 1826 a 1829”, organizado na década de 1870 pelo então secretário da Câmara Antonio Pereira Pinto. Numa avaliação quantitativa abrangendo resoluções e projetos de lei oriundos da Câmara, no fim 
da primeira legislatura achavam-se pendentes no Senado 11 matérias de 1827 e 14 de 1828. Anais da Assembléia Geral Legislativa do Império do Brasil: 1826-1831.

${ }^{18}$ Uma crítica fundamental dos revolucionários pernambucanos de 1824 fora a de que a Câmara ficara "quase escrava" do Senado (CANECA, Frei Joaquim do Amor Divino. Obras políticas e literárias. Recife: Typographia Mercantil, v.1, p.44, 1875).

${ }^{19}$ Citado em RIZZINI, C. Hipólito da Costa e o Correio Braziliense. São Paulo: Cia. Ed. Nacional, 1957, p.254.

${ }^{20}$ Sobre o tema, consulte-se ELIAS, N. O Processo civilizador: formação do Estado e civilização. Rio de Janeiro: Jorge Zahar Ed., v.2, 1993.

${ }^{21}$ Sobre a questão da fiscalidade no período, consultar: COSTA, W. P. Do domínio à nação: os impasses da fiscalidade no processo de Independência. In: JANCSÓ, István (Org.) Brasil: formação do Estado e da Nação. São Paulo: Hucitec/Fapesp, 2003.

Artigo recebido em junho de 2007. Aprovado em março de 2008. 